\title{
Assessment of trace element accumulation on the Tunisian coasts using biochemical biomarkers in Perinereis cultrifera
}

\author{
Marwa Bouhedi ${ }^{1}$, Mouna Antit ${ }^{1}$, Marwa Chaibi ${ }^{1}$, Hanane Perrein-Ettajani ${ }^{2}$, Patrick Gillet ${ }^{2}$, \\ Atf Azzouna ${ }^{1}$ \\ ${ }^{1}$ Laboratory of Ecology, Biology and Physiology of Aquatic Organisms, Department of Biology, Faculty of Sciences of \\ Tunis, University of Tunis El Manar, 2092 Tunis, Tunisia. \\ (MB) (Corresponding author) E-mail: marwa.bouhedi@ fst.utm.tn. ORCID iD: https://orcid.org/0000-0002-2705-7483 \\ (MA) E-mail: antit_mouna@yahoo.fr. ORCID iD: https://orcid.org/0000-0002-0420-7119 \\ (MC) E-mail: Marwachaibi89@ gmail.com. ORCID iD: https://orcid.org/0000-0001-5958-4213 \\ (AA) E-mail: atf.azzouna@fst.utm.tn. ORCID iD: https://orcid.org/0000-0002-5606-5239 \\ ${ }^{2}$ Mer Molécules Santé, Department of Biology Environment, Faculty of Sciences, UCO Angers, France. \\ (HP-E) E-mail: hperrein@uco.fr. ORCID iD: https://orcid.org/0000-0002-4195-3137 \\ (PG) E-mail: pgillet@uco.fr. ORCID iD: https://orcid.org/0000-0002-7183-9685
}

\begin{abstract}
Summary: Our study aimed to evaluate the effect of trace element pollution in the polychaete Perinereis cultrifera (Grube, 1840) from two Tunisian coasts (the port of Rades, S1; and the Punic port of Carthage, S2). To this end, we used an approach based on proximate composition, biomarker responses and trace element bioaccumulation. Our results showed a decreasing order of metals concentrations $(\mathrm{Zn}>\mathrm{Cu}>\mathrm{Cd}>\mathrm{Pb})$ in $P$. cultrifera from $\mathrm{S} 1$ and $\mathrm{S} 2$. The accumulation of $\mathrm{Cd}, \mathrm{Cu}$ and $\mathrm{Zn}$ was significantly higher in S1 than in S2, especially in summer. Lipid, protein and glycogen content also changed significantly between S1 and S2 in relation to trace metal accumulation and environmental conditions. The results revealed a higher level of thiobarbituric acid in P. cultrifera from S1 than from S2. In addition, the enzymatic and non-enzymatic antioxidant defence system (catalase, glutathione-S-transferase, superoxide dismutase, glutathione and metallothionein) was enhanced and acetylcholinesterase activities decreased in $P$. cultrifera in S1 in comparison with $\mathrm{S} 2$. A principal component analysis showed that $P$. cultrifera from S1 exhibited a clear disruption of oxidative stress responses and trace element bioaccumulation among seasons. Overall, these findings revealed the sensitivity of those organisms to environmental conditions.
\end{abstract}

Keywords: polychaete; coastal pollution; Gulf of Tunis; oxidative stress; environmental conditions; metallic pollution.

Evaluación de la acumulación de elementos traza en las costas tunecinas mediante el uso de biomarcadores bioquímicos en Perinereis cultrifera

Resumen: Nuestro estudio tenía como objetivo evaluar el efecto de la contaminación por elementos traza en el poliqueto Perinereis cultrifera (Grube, 1840) de dos costas tunecinas (S1: el puerto de Rades; S2: el puerto púnico de Cartago). Para ello, hemos utilizado un enfoque basado en la composición proximal, las respuestas de los biomarcadores y la bioacumulación de elementos traza. Nuestros resultados mostraron un orden decreciente de las concentraciones de metales $(\mathrm{Zn}>\mathrm{Cu}>\mathrm{Cd}>\mathrm{Pb})$ en $P$. cultrifera de S1 y S2. Nuestros datos mostraron una acumulación significativa de $\mathrm{Cd}$, $\mathrm{Cu}$ y $\mathrm{Zn}$ en $P$. cultrifera recolectada en el puerto de Rades (S1), especialmente durante la temporada de verano, en comparación con las del puerto púnico de Cartago (S2). Asimismo, los contenidos de lípidos, proteínas y glicógenos cambiaron significativamente entre S1 y S2 en relación con la acumulación de metales y las condiciones ambientales. Los resultados obtenidos revelaron un aumento del nivel de ácido barbitúrico (TBARS) en $P$. cultrifera de S1 en comparación con S2. Además, se observó un aumento significativo del sistema de defensa antioxidante enzimático y no enzimático (catalasa CAT, glutación-S-transferasa: GST, superóxido dismutasa: SOD, glutatión: GSH y metaloproteína: MT) y una disminución de las actividades de la acetilcolinesterasa (AChE) se observaron en P. cultrifera del puerto de Rades (S1) en comparación con las del puerto púnico de Cartago (S2). El análisis de componentes principales (PCA) mostró que la $P$. cultrifera de $\mathrm{S} 1$ presentaba una clara alteración de las respuestas al estrés oxidativo y la bioacumulación de elementos traza entre las estaciones. En general, estos resultados revelaron la sensibilidad de estos organismos frente a las condiciones ambientales

Palabras clave: poliquetos; contaminación costera; golfo de Túnez; estrés oxidativo; condiciones ambientales; contaminación metálica.

Citation/Como citar este artículo: Bouhedi M., Antit M., Chaibi M., Perrein-Ettajani H., Gillet P., Azzouna A. 2021. Assessment of trace element accumulation on the Tunisian coasts using biochemical biomarkers in Perinereis cultrifera. Sci. Mar. 85(2): 91-102. https://doi.org/10.3989/scimar.05099.009

Editor: R. Sardà.

Received: July 1, 2020. Accepted: February 22, 2021. Published: May 28, 2021.

Copyright: ( $) 2021$ CSIC. This is an open-access article distributed under the terms of the Creative Commons Attribution 4.0 International (CC BY 4.0) License. 


\section{INTRODUCTION}

The daily discharge of pollutants from human activities such as industry, agriculture, shipping, ports, domestic waste and anthropogenic pressure is a serious problem that has harmful effects on aquatic organisms (Paraskevopoulou et al. 2014). Many animals and plants living in polluted environments are often exposed to complex mixtures of chemical contaminants (Sureda et al. 2011), and these species have been proposed as a biomonitor of pollutants in coastal areas (Bodin et al. 2011). Polychaetes (Annelida) have been used as sentinels in coastal studies for monitoring purposes, especially in soft-bottom habitats ( $\mathrm{Li}$ et al. 2012). These worms are one of the most important groups in terms of diversity and abundance in macro-benthic communities in coastal and marine environments, (Chouikh et al. 2019). They play a vital role in ecosystem functioning, not only because of their dominance, but also because of their different feeding modes and reproductive strategies (Han et al. 2016).

Scientists and environmental managers are currently working for a more specific concept of biomonitoring of the marine environment based on the study of the biological response by analysing bioaccumulation of metals, which are of particular concern due to their toxic effect, their persistence and their tendency to bioaccumulate and spread throughout food chains (Yi et al. 2008). Due to the complex stress responses influenced by metals, metalloids and their mixtures, it is important to create a battery of biomarkers that represent different roles and biological levels, such as the variation of oxidative stress (Di Salvatore et al. 2013, Bejaoui et al. 2017) and trace element concentration (Di Salvatore et al. 2013, Sureda et al. 2011), which can be linked to whole-organism responses and ecological responses to indicate the presence of harmful substances in the marine environment (Cravo et al. 2012). The toxicity of metals has been attributed mainly to their capacity to increase the generation of reactive oxygen species (ROS), which are thought to be the main cause of lipid and protein peroxidation (Chetoui et al. 2019). To neutralize free radicals and counteract the deleterious effects of ROS, cells possess an antioxidant defence system (Halliwell 2007).

In this study, the marine polychaete Perinereis cultrifera (Grube, 1840) was used as a biological model. It is present on the northwestern coasts of Europe, the Mediterranean Sea, the Atlantic, and the Indian and Pacific Oceans (Durchon 1957, Wu et al. 1985). In Tunisia, it is widespread but poorly documented (Zghal and Ben Amor 1989). According to the literature, P. cultrifera is an intertidal species, inhabiting rocky coasts under stones and boulders, usually where there is an accumulation of sediment (Scaps et al. 1992). Other studies have shown that this species can live in muddy sediments (Ghirardini et al. 1999). The mode of reproduction of $P$. cultrifera differs widely according to the geographical situation of the populations. It has a lifespan of three years and reproduces by epitokous or atokous (Scaps et al. 1992, Rouabah and Scaps 2003). In Tunisia, no studies on the reproduction of $P$. cultrifera have been carried out.

Several studies have reported that $P$. cultrifera is a suitable bioindicator species of marine pollution (Gue- mouda et al. 2014, Snani et al. 2015, Meghlaoui et al. 2015). However, no study has been carried out on $P$. cultrifera responses to anthropogenic pollution on the Tunisian coast. The present study is the first to evaluate the effect of environmental trace element bioaccumulation on the redox status system (lipid peroxidation, neurotoxicity and biomarker responses) and the biochemical reserves in whole tissues of $P$. cultrifera from two sites in relation to seasonal variation.

\section{MATERIALS AND METHODS}

\section{Study areas}

In the current study, sampling sites were chosen for the presence of $P$. cultrifera and the potential impact of pollution in the Gulf of Tunis. This gulf is located between the western Mediterranean basin and the western boundary of the eastern basin. The area is characterized by dynamic and diverse benthic communities, which have often been the subject of environmental studies (Antit 2012). For a few years, the littoral of the Gulf of Tunis has been the focus of intensive agriculture, industry, urban development and tourism. Consequently, the coastal zone of the Gulf of Tunis has been submitted to the impact of many chemical and physical stressors (Tlili et al. 2013). Two sites in the Gulf of Tunis differing in their level of contamination were selected for this study (Fig. 1). The port of Rades (S1) (3648.6'N, 10¹7.1'E) is considered a polluted area because of its location in front of the industrial complex of Tunis Bay (chemical and metallurgic industries) and its intense maritime traffic (Antit 2012, Tlili et al. 2013). According to Souissi et al. (2000), the port of Rades is generally eutrophic because of the nutrient enrichment caused by urban and industrial discharges through the Rades canal and the influence of land-based inputs. However, the Punic port of Carthage (S2) (36 50'41.28'N, 10¹9'37.92' E) is considered to have undergone eutrophication, which is caused by increased nutrient loading as a result of rapidly expanding human population growth in the region since 1990 (Aissaoui et al. 2014).

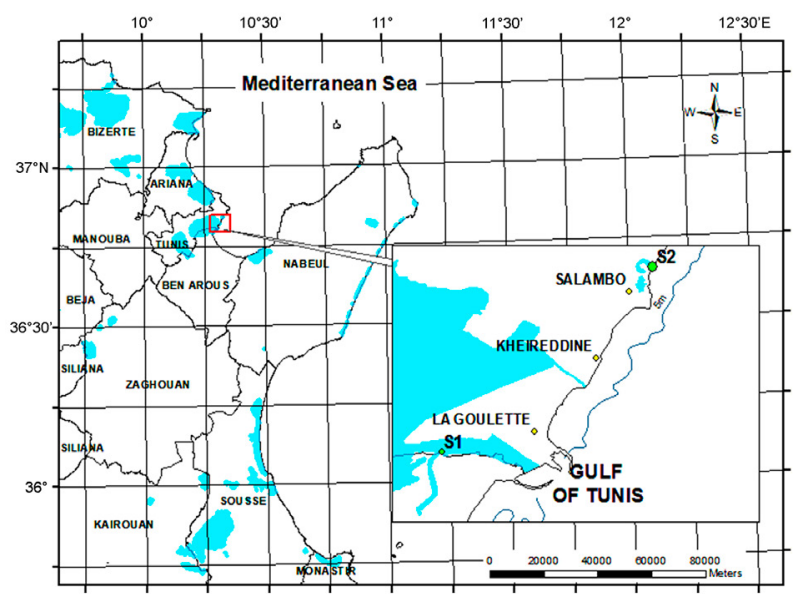

Fig. 1. - Map of the sampling sites in the Gulf of Tunis (Tunisia): S1, port of Rades; S2, Punic port of Carthage. Blue colour signifies the sea. 


\section{Sampling species and treatments}

About 40 individuals $(\mathrm{n}=40)$ of $P$. cultrifera ( $\mathrm{S} 1$, $9.09 \pm 1.3 \mathrm{~cm}$ length and $0.58 \pm 0.05 \mathrm{~g}$ weight; $\mathrm{S} 2$, $10.04 \pm 0.98 \mathrm{~cm}$ length and $0.63 \pm 0.02 \mathrm{~g}$ weight) were seasonally collected by hand from the two study sites in 2017-2018. They were collected in a sandy-muddy substrate where the species lives under sandy stones or even in the mud (upper $20 \mathrm{~cm}$ depth). After collection, specimens were transported to the laboratory. $P$. cultrifera $(\mathrm{n}=6$ of 20 pooled individuals each season) were immediately frozen in liquid nitrogen for trace element quantification. All procedures of biomarker quantification were carried out at 0 to $4^{\circ} \mathrm{C}$. As the influence of weight on biomarkers in different aquatic species has been previously reported, animals in the same tissue weight range were selected for the entire sampling period and for each site (Mouneyrac et al. 2000). For each sampling period and site, specimens $(\mathrm{n}=20$ individuals) were homogenized by hand in liquid nitrogen with a porcelain mortar and pestle. The powder obtained was then homogenized with a motorized grinder with $1.5 \mathrm{~mL}$ citrate buffer at $\mathrm{pH} 5.0$ for analysis for glycogen and lipids. Prior to protein analysis, specimens were ground in Tris-HCL (Trizma-base hydrochloric acid) buffer $(0.8 \mathrm{M}, \mathrm{pH} 7.2)$ and centrifuged at $9000 \mathrm{~g}$ for $30 \mathrm{~min}$ at $4^{\circ} \mathrm{C}$. The obtained supernatants were stored at $-80^{\circ} \mathrm{C}$ until analysis.

\section{Physico-chemical parameters}

The physico-chemical parameters of the sampling areas were measured three times each season. Seawater temperature $\left(\mathrm{T}^{\circ} \mathrm{C}\right)$ was measured with a thermometer (model WTW.LF.325), salinity (S psu) was measured with salinity-conductivity (model WTW.LF.325) and pH was measured using a pH meter (model WTW.LF.325). The amounts of suspended particulate matter (SPM) and chlorophyll $a(\mathrm{Chl} a$ ) were determined according to the method of Aminot and Chaussepied (1983).

\section{Trace element analysis}

Concentrations of cadmium $(\mathrm{Cd})$, copper $(\mathrm{Cu})$, lead $(\mathrm{Pb})$ and zinc $(\mathrm{Zn})$ were determined in dried tissue for $48 \mathrm{~h}$ at $60^{\circ} \mathrm{C}$. Sample powders were mineralized in a closed microwave (Milestone Inc.) using nitric acid and hydrogen peroxide mineralization. The resulting digestates were used to determine $\mathrm{Cd}, \mathrm{Cu}, \mathrm{Pb}$ and $\mathrm{Zn}$ by inductively coupled plasma mass spectrometry (ICP-MS, PerkinElmer Inc.). The analytical procedure was checked using CRM-278R certified standard reference material. Results are expressed as mg per $\mathrm{kg}$ of dry weight. The extraction efficiencies for the tested trace elements were as follows: $\mathrm{Cd}=93 \% ; \mathrm{Cu}=94 \% ; \mathrm{Pb}=94 \%$; and $\mathrm{Zn}=95 \%$.

\section{Biochemical analysis}

\section{Protein quantification}

The protein content in the supernatant was determined according to the method of Bradford (1976) using Coomassie Blue as a reagent. Results are detected at $700 \mathrm{~m}$ using a microplate reader (Corning 9017) and are expressed as mg per $\mathrm{g}$ of tissue.

\section{Lipid quantification}

Total lipid concentration was analysed according to the method of Frings et al. (1972), using a sulfophosphovanillin reaction. The United States grade of olive oil (Sigma, St. Louis, USA) was used as a standard. Results were calculated by reference to a standard curve and expressed as $\mathrm{mg} / \mathrm{g}$ of ww.

\section{Glycogen quantification}

Glycogen concentrations were estimated in two aliquots of the homogenate, one of which was submitted to enzymatic digestion by amyloglucosidase according to Carr and Neff (1984). Data were expressed as $\mathrm{mg} / \mathrm{g}$ of ww.

Lipids and glycogen values were measured using colorimetric spectroscopy on a 96-well microplate reader (Corning 9017) at 540 and $420 \mathrm{~nm}$, respectively.

\section{Biomarker analysis}

\section{Thiobarbituric acid reactive substances}

The concentration of thiobarbituric acid reactive substances (TBARS) was measured spectrophotometrically according to the method described by Knight et al. (1988). An aliquot of $0.5 \mathrm{~mL}$ of tissue extract supernatant was mixed with $1 \mathrm{~mL}$ of trichloro-acetic acid solution and centrifuged at $2500 \times \mathrm{g}$ for $10 \mathrm{~min}$. An aliquot of thiobarbituric acid (TBA) solution and 0.5 $\mathrm{mL}$ of supernatant was incubated for $45 \mathrm{~min}$ at $90^{\circ} \mathrm{C}$ and cooled. The absorbance of TBA-MDA complex was determined at $532 \mathrm{~nm}$ using a spectrophotometer. Lipid peroxidation was expressed as nmol of TBARS, using 1,1,3,3-tetra-ethoxypropane as standard. Results are expressed as nmols of MDA per mg of protein.

\section{Acetylcholinesterase activity}

Acetylcholinesterase (AChE) activity was determined according to the method described by Ellman et al. (1961). The method is based on a coupled enzyme reaction involving acetylthiocholine as the specific substrate for AChE and 5,5'-dithio-bis-2-nitrobenzoate as an indicator for the enzyme reaction. The enzymatic reaction rate was measured spectrophotometrically at $412 \mathrm{~nm}$. Results are expressed as nmol of substrate per min per mg of protein.

\section{Enzymatic antioxidants}

Glutathione S-transferase (GST) activity was determined according to Habig et al. (1974), using 1-chloro-2,4-dinitrobenzene as a substrate and glutathione $(\mathrm{GSH})$ in $100 \mathrm{mM}$ potassium phosphate buffer, $\mathrm{pH}$ 6.5. Absorbance was measured at $340 \mathrm{~nm}$, and activities were expressed as nmol of conjugated product formed per min per $\mathrm{mg}$ of protein. 
Catalase (CAT) activity was measured following the method described by Aebi (1984) as a result of the decrease in absorbance at $240 \mathrm{~nm}$ due to the consumption of hydrogen peroxide $\left(\mathrm{H}_{2} \mathrm{O}_{2}\right)$. The results are expressed as $\mu$ mol of $\mathrm{H}_{2} \mathrm{O}_{2}$ consumed per min per mg of protein.

Superoxide dismutase (SOD) activity was evaluated by spectrophotometrically methods at $560 \mathrm{~nm}$ based on Beauchamp and Fridovich (1971). The obtained results were expressed as U per mg of protein.

\section{Non-enzymatic antioxidants}

Metallothionein (MT) level was estimated based on the method described by Viarengo et al. (1997) and modified by Petrovic et al. (2001). The absorbance was determined at $412 \mathrm{~nm}$. The results were expressed as $\mu \mathrm{mol}$ of GSH per mg of protein.

Reduced GSH level in the P. cultrifera tissue was analysed at $412 \mathrm{~nm}$ by the Ellman (1959) method modified by Jollow et al. (1974), and the results were expressed as nmol per $\mathrm{mg}$ of protein.

\section{Data analysis}

\section{Risk assessment trace metal indices}

To compare trace element levels in each sampled individual for overall spatial and temporal variability, the metal pollution index (MPI) was determined as described by Usero et al. (2005):

$$
\mathrm{MPI}=(\mathrm{Cf} 1 \times \mathrm{Cf} 2 \ldots \mathrm{Cfn}) 1 / \mathrm{n}
$$

where Cfn is the concentration of TEs $\mathrm{n}$ in the $P$. cultrifera tissue.

\section{Statistical analysis}

The results are expressed as means \pm standard deviation (sd). The experimental data were initially tested for normality and homogeneity to meet the statistical demands. The statistical analysis between the tested population and seasons was performed using one-way ANOVA and Duncan's test and the observed difference at $\mathrm{p}<0.05$ was considered significant. The whole data set of the biomarker responses, metal accumulation and biochemical contents in $P$. cultrifera was processed statistically by principal component analysis (PCA) and correlation matrix using STATISTICA software (version 13.2).

\section{RESULTS}

\section{Abiotic parameters}

The physico-chemical parameters are presented in Table 1 . The most variation was recorded in summer, as evidenced by significantly lower $\mathrm{T}^{\circ} \mathrm{C}, \mathrm{SPM}$ and $\mathrm{Chl} a$ in $\mathrm{S} 2$ than in $\mathrm{S} 1$ ( $\mathrm{p}<0.05$; one-way ANOVA). Additionally, only SPM was significantly lower in S2 in spring $(\mathrm{p}<0.05$, one-way ANOVA) and autumn $(\mathrm{p}<0.01$, oneway ANOVA). However, in winter, no change was noticed between the sampling sites. Summer exhibited the highest values of $\mathrm{T}^{\circ} \mathrm{C}$ and SPM and the lowest values of $\mathrm{Chl} a$ for both the sampling sites $(\mathrm{p}<0.01$, one-way ANOVA).

\section{Trace element concentrations in $\boldsymbol{P}$. cultrifera tissues}

The metal concentrations recorded in P. cultrifera are presented in Table 2. Zn exhibited the highest content followed by $\mathrm{Cu}, \mathrm{Cd}$ and $\mathrm{Pb}$. There was a significantly higher accumulation of $\mathrm{Cd}, \mathrm{Zn}$ and $\mathrm{Cu}$ in spring in $P$. cultrifera from $\mathrm{S} 1$ than from $\mathrm{S} 2$ ( $\mathrm{p}<0.01$, one-way ANOVA). Also, $\mathrm{Zn}$ and $\mathrm{Cu}$ were significantly higher in $P$. cultrifera collected from $\mathrm{S} 1$ in summer $(\mathrm{p}<0.01$, one-way ANOVA). Only $\mathrm{Cd}$ and $\mathrm{Zn}$ were higher in the $P$. cultrifera from $\mathrm{S} 1$ than from $\mathrm{S} 2$ in the cold seasons (autumn and winter, respectively). The greatest accumulation was observed in summer for both $P$. cultrifera populations ( $\mathrm{p}<0.05$, one-way ANOVA).

Table 1. - Seasonal variation of the physico-chemical parameters of sampling sites S1 (the port of Rades) and S2 (the Punic port of Carthage) in $2017 / 2018$

\begin{tabular}{|c|c|c|c|c|c|}
\hline & Sites & Spring & Summer & Autumn & Winter \\
\hline \multirow{2}{*}{ Temperature $\left({ }^{\circ} \mathrm{C}\right)$} & $\mathrm{S} 1$ & $35.93 \pm 5.77$ & $41.83 \pm 2.56^{\# \#}$ & $34.43 \pm 4.06$ & $27.41 \pm 2.91$ \\
\hline & $\mathrm{S} 2$ & $35.18 \pm 1.23$ & $38.31 \pm 1.08^{* * \#}$ & $34.25 \pm 1.47$ & $27.61 \pm 2.45$ \\
\hline \multirow{2}{*}{ Salinity (psu) } & $\mathrm{S} 1$ & $32.83 \pm 0.28$ & $34.40 \pm 0.52$ & $30.33 \pm 0.57$ & $28.50 \pm 0.50$ \\
\hline & $\mathrm{S} 2$ & $32.41 \pm 0.52$ & $35.06 \pm 0.30$ & $30.16 \pm 0.25$ & $28.10 \pm 0.26$ \\
\hline \multirow{2}{*}{$\mathrm{pH}$} & $\mathrm{S} 1$ & $8.03 \pm 0.01$ & $8.10 \pm 0.09$ & $8.13 \pm 0.05$ & $8.13 \pm 0.11$ \\
\hline & $\mathrm{S} 2$ & $8.01 \pm 0.02$ & $8.05 \pm 0.05$ & $8.05 \pm 0.05$ & $8.00 \pm 0.01$ \\
\hline \multirow{2}{*}{ Suspended matter $(\mathrm{mg} / \mathrm{L})$} & $\mathrm{S} 1$ & $907.66 \pm 79.47$ & $1003.33 \pm 55.75^{\# \#}$ & $738.50 \pm 33.75$ & $595.66 \pm 46.50$ \\
\hline & $\mathrm{S} 2$ & $813.33 \pm 73.71^{*}$ & $900.00 \pm 45.82^{* * \# \#}$ & $660.00 \pm 62.44^{* *}$ & $563.33 \pm 47.25$ \\
\hline \multirow{2}{*}{ Chlorophyll $a(\mu \mathrm{g} / \mathrm{cm} 3)$} & $\mathrm{S} 1$ & $1.94 \pm 0.19$ & $1.09 \pm 0.20^{\# \#}$ & $1.49 \pm 0.16$ & $1.57 \pm 0.14$ \\
\hline & $\mathrm{S} 2$ & $1.92 \pm 0.07$ & $1.02 \pm 0.01^{* * \# \#}$ & $1.55 \pm 0.14$ & $1.55 \pm 0.04$ \\
\hline
\end{tabular}

The results are represented as mean $\pm \mathrm{sd}(\mathrm{n}=3)$

The statistical differences between sampling sites are represented at $5 \%$ : $* \mathrm{p}<0.05 ; * * \mathrm{p}<0.01 ; * * * \mathrm{p}<0.001$ using one-way ANOVA.

The statistical differences between seasons are represented at $5 \%$ : \#p $<0.05$; \#\#p $<0.01 ; \# \# \#$ $<0.001$ using one-way ANOVA. 
Table 2. - Seasonal variation of trace element concentrations (Cd, cadmium; $\mathrm{Cu}$, copper; $\mathrm{Pb}$, lead; $\mathrm{Zn}$, zinc) in $P$. cultrifera tissues collected from S1 (the port of Rades) and S2 (the Punic port of Carthage).

\begin{tabular}{|c|c|c|c|c|c|c|}
\hline$\mu \mathrm{g} \mathrm{g}^{-1}$ of $\mathrm{DW}$ & Sites & Spring & Summer & Autumn & Winter & CRM 278R \\
\hline $\mathrm{Cd}$ & $\begin{array}{l}\mathrm{S} 1 \\
\mathrm{~S} 2\end{array}$ & $\begin{array}{c}0.37 \pm 0.01 \\
0.19 \pm 0.03^{* * *}\end{array}$ & $\begin{array}{c}0.34 \pm 0.11 \\
0.51 \pm 0.03 \# \# \#\end{array}$ & $\begin{array}{l}0.43 \pm 0.10 \# \# \\
0.22 \pm 0.09 * *\end{array}$ & $\begin{array}{c}0.21 \pm 0.03 \\
0.30 \pm 0.10^{*}\end{array}$ & $0.34 \pm 0.00$ \\
\hline $\mathrm{Zn}$ & $\begin{array}{l}\mathrm{S} 1 \\
\mathrm{~S} 2\end{array}$ & $\begin{array}{c}79.97 \pm 0.02 \\
56.42 \pm 1.81 * * *\end{array}$ & $\begin{array}{c}89.67 \pm 0.03 \# \\
53.49 \pm 0.81 * * *\end{array}$ & 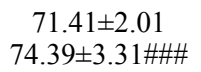 & $\begin{array}{c}71.03 \pm 0.02 \\
52.35 \pm 1.99 * * *\end{array}$ & $83.100 \pm 1.7$ \\
\hline $\mathrm{Cu}$ & $\begin{array}{l}\mathrm{S} 1 \\
\mathrm{~S} 2\end{array}$ & $\begin{array}{c}5.70 \pm 0.22 \\
4.95 \pm 0.49 * *\end{array}$ & $\begin{array}{c}6.88 \pm 0.03 \\
3.39 \pm 0.19 * * \# \#\end{array}$ & $\begin{array}{l}6.78 \pm 0.01 \\
6.79 \pm 0.29\end{array}$ & $\begin{array}{l}5.76 \pm 0.02 \\
5.98 \pm 0.60\end{array}$ & $9.45 \pm 0.13$ \\
\hline $\mathrm{Pb}$ & $\begin{array}{l}\mathrm{S} 1 \\
\mathrm{~S} 2\end{array}$ & $\begin{array}{c}0.06 \pm 0.02 \\
0.06 \pm 0.005\end{array}$ & $\begin{array}{l}0.06 \pm 0.01 \\
0.06 \pm 0.02\end{array}$ & $\begin{array}{c}0.06 \pm 0.02 \\
0.06 \pm 0.005\end{array}$ & $\begin{array}{c}0.06 \pm 0.006 \\
0.06 \pm 0.01\end{array}$ & $2.00 \pm 0.04$ \\
\hline
\end{tabular}

The results are represented as mean $\pm \mathrm{sd}(\mathrm{n}=6$ pooled individuals).

The statistical differences between sampling sites are represented at 5\%: *p<0.05; **p $<0.01 ; * * * \mathrm{p}<0.001$ using one-way ANOVA.

The statistical differences between seasons are represented at 5\%: \#p<0.05; \#\#p<0.01; \#\#\#p<0.001 using one-way ANOVA.

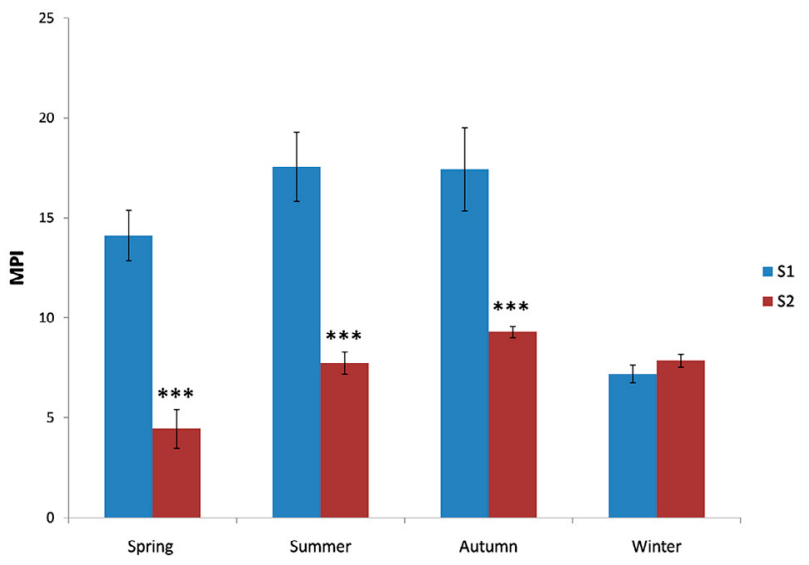

Fig.2. - Seasonal variation of the metal pollution index (MPI) in $P$. cultrifera tissues collected from the port of Rades (S1) and the Punic port of Carthage (S2). (The results are represented as mean $\pm \mathrm{sd}[\mathrm{n}=6])$. The statistical differences between sampling sites are represented at $5 \%$ : $* p<0.05 ; * * p<0.01$ and $* * * p<0.001$ using one-way ANOVA. The statistical differences between seasons are represented at 5\%: $\# p<0.05 ; \# \# p<0.01$ and $\# \# \# p<0.001$ using one-way ANOVA.

\section{Risk assessment of trace metals in $P$. cultrifera tissues}

MPI values are presented in Figure 2. Our results demonstrated that this index was significantly higher in $P$. cultrifera from $\mathrm{S} 1$ in spring, summer and autumn $(\mathrm{p}<0.001$, one-way ANOVA). However, no change was recorded in winter.

\section{Proximate composition in $P$. cultrifera tissues}

\section{Glycogen contents}

Glycogen content was significantly higher in S2 than in $\mathrm{S} 1$ in spring and autumn $(\mathrm{p}<0.05$, one-way ANOVA), but no significant variation was observed in summer and winter. A significant decrease was observed in summer in both $\mathrm{S} 1(\mathrm{p}<0.01$, one-way ANOVA) and S2 ( $<<0.001$, one-way ANOVA) (Fig. 3A).

\section{Lipids contents}

Lipid content was higher in $\mathrm{S} 2$ than in $\mathrm{S} 1$ in spring, summer and winter $(\mathrm{p}<0.01$, one-way ANOVA). However, no significant variation was observed in autumn. Lipid content was highest in winter for both populations, while only $\mathrm{S} 1$ showed a significant decrease in lipid content in summer $(\mathrm{p}<0.05$, one-way ANOVA) (Fig. 3B).

\section{Protein contents}

Protein content was significantly higher in S2 than in S1 (Fig. 3C) across seasons, but was significantly lower in summer for both populations $(\mathrm{p}<0.001$, oneway ANOVA).

\section{Biomarker responses}

\section{Thiobarbaturic acid level in P. cultrifera tissues}

TBARS levels in $P$. cultrifera collected from $\mathrm{S} 1$ and $\mathrm{S} 2$ are presented in Table 3. Our results showed significantly higher TBARS levels in spring (53\%), summer $(65 \%)$ and autumn $(64 \%)$ in S1 than in S2. However, in winter the levels of TBARS remained invariable between the populations. The highest levels were recorded in summer in S1 $(5.01 \pm 0.14)$ and S2 (3.63 \pm 0.32$)$ $(\mathrm{p}<0.05$, one-way ANOVA).

\section{Acetylcholinesterase activity in P. cultrifera tissues}

Seasonal variations in AChE activity in P. cultrifera tissues are presented in Table 3 . Our results revealed significantly lower AChE activities in $\mathrm{S} 1$ than in S2 in spring, summer and winter $(\mathrm{p}<0.05$, oneway ANOVA). However, a similar trend of AChE activity was observed between S1 and S2 in autumn. AChE activity appeared to be significantly lower in summer and autumn in both populations $(\mathrm{p}<0.001$, one-way ANOVA). 


\section{Enzymatic antioxidants}

Glutathione S-transferase activity in $\mathrm{P}$. cultrifera tissues

GST activity in $P$. cultrifera tissues is presented in Table 3. GST activity was significantly higher in summer (36\%) and winter $(89 \%)$ in S1 than in S2. However, no significant change was observed in spring and autumn. GST activity higher in both populations was significantly in summer than in the other seasons ( $\mathrm{p}<0.001$, one-way ANOVA).

\section{Catalase activity in $\mathrm{P}$. cultrifera tissues}

CAT activity in both studied populations is summarized in Table 3. CAT activity was significantly higher in $\mathrm{S} 1$ than in $\mathrm{S} 2$ in all seasons ( $\mathrm{p}<0.05$, one-way ANOVA). CAT activity in both populations was significantly higher in summer $(\mathrm{p}<0.001$, one-way ANOVA) than in the other seasons $(\mathrm{p}<0.01$, one-way ANOVA).

Superoxide dismutase activity in $\mathrm{P}$. cultrifera tissues

SOD activity was significantly higher in $\mathrm{S} 1$ than in $\mathrm{S} 2$

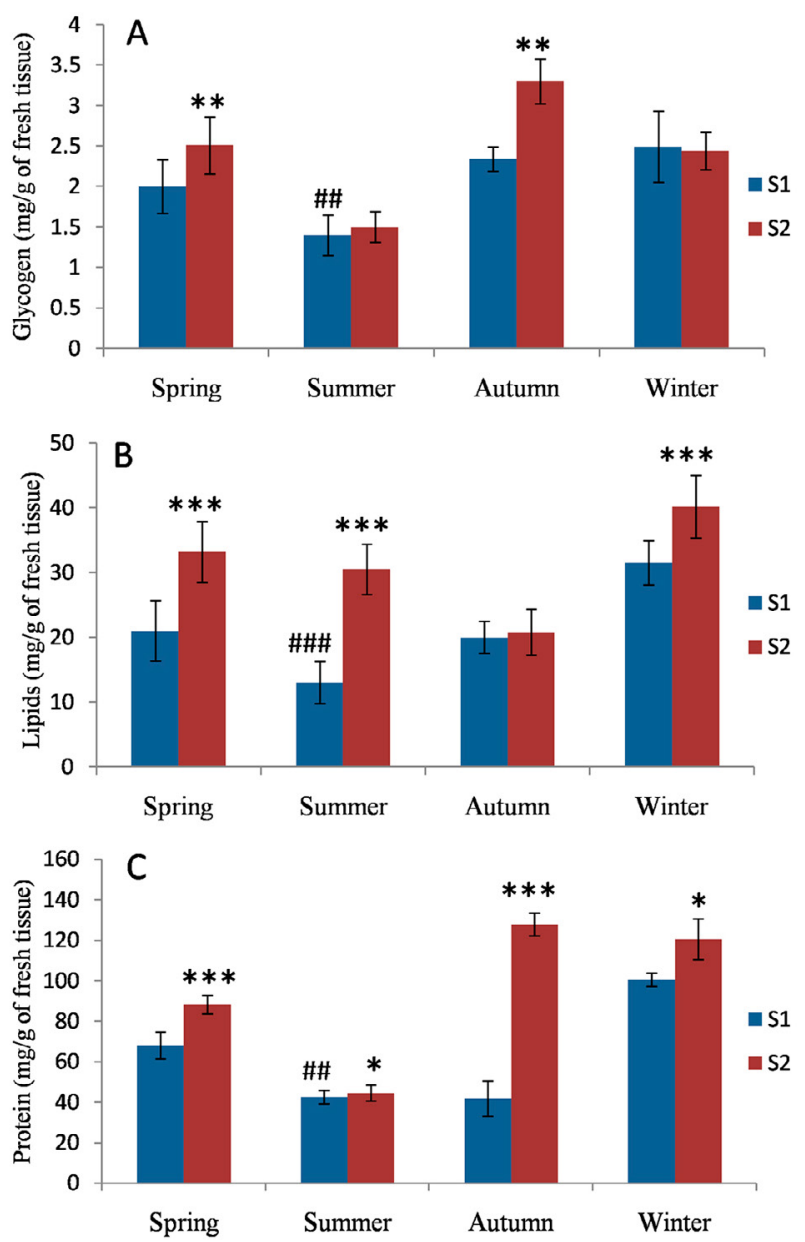

Fig.3. - Seasonal variation in the proximate fraction $(\mathrm{mg} / \mathrm{g} \mathrm{ww})$ of $P$. cultrifera tissues collected from the port of Rades (S1) and the Punic port of Carthage (S2). (The results are represented as mean \pm sd $[n=20])$. The statistical differences between sampling sites are represented at $5 \%$ : ${ }^{*} \mathrm{p}<0.05 ; * * \mathrm{p}<0.01$ and $* * * \mathrm{p}<0.001$ using one-way ANOVA. The statistical differences between seasons are represented at 5\%: $\# p<0.05 ; \# \# p<0.01$ and \#\#\#p<0.001 using oneway ANOVA. in spring (48\%), summer (11\%) and autumn (15\%) (Table 3). SOD activity was significantly higher in spring and summer in both populations ( $\mathrm{p}<0.05$, one-way ANOVA).

\section{Non-enzymatic antioxidants}

\section{Metallothionein (MT) level in P. cultrifera tissues}

The MT level was significantly higher in summer than in the other seasons for both populations $(\mathrm{p}<0.05$, one-way ANOVA). The MT level was $40 \%$ and $21 \%$ higher in S1 than in S2 in spring and summer, respectively (Table 3). However, no significant difference was observed between the sites in autumn and winter.

\section{Glutathione level in P. cultrifera tissues}

Summer showed the highest GSH level in both populations $(\mathrm{p}<0.05$, one-way ANOVA). The results for GSH levels of $P$. cultrifera tissues are presented in Table 3. Although GSH levels were higher in $\mathrm{S} 1$ than in S2 in spring (40\%) and summer (20\%), they were not statistically different in autumn and winter.

\section{Principal component analysis}

The results of the PCA are presented in Figure 4, which has input from key factor axes and shows the correlation circle and the projection of individuals (seasons) on the factorial design (1: 2). This analysis allowed us to retain the first two factorial axes, which explained $68.81 \%$ of the total variance. The first axis contributed the maximum dispersion $(50.49 \%$ of the total) and correlated negatively with CAT, GST, TBARS, GSH, MTs, SOD, Cd, temperature, salinity, and SPM (Fig. 4). However, only protein, glycogen and $\mathrm{Chl} a$ were correlated positively with the first axis. The second axis was described by $18.32 \%$ of the total dispersion. This axis showed a positive correlation with $\mathrm{Zn}, \mathrm{Cu}$ and $\mathrm{pH}$ and a negative correlation with lipid content. The screening of individuals (sites/seasons) on the same factorial showed different clusters. The first one, which included specimens taken from $\mathrm{S} 1$ and $\mathrm{S} 2$ in summer, coincided with the higher levels of TBARS, GSH, GST, CAT, Cd, Zn, salinity, temperature and SPM. Also, specimens taken from S2 in winter were showed a high lipid content and AChE activity. However, data observed at both S1 and $\mathrm{S} 2$ in spring, autumn and winter (only for S1) showed the highest activity of $\mathrm{Cu}$, glycogen, $\mathrm{Chl} a$ and protein.

\section{Correlation matrix between trace metals and tested parameters in $\boldsymbol{P}$. cultrifera tissues}

The statistical analyses were performed between the tested parameters and the study sites (Table 4). The correlations were recorded between $\mathrm{Cd}, \mathrm{Zn} \mathrm{Cu}, \mathrm{Pb}$ and all of the redox status parameters. AChE activity and protein, glycogen and lipid content showed significant negative correlations with temperature $(\mathrm{p}<0.05)$, salinity $(\mathrm{p}<0.01)$, suspended matter $(\mathrm{p}<0.01)$ and trace metals accumulation $(\mathrm{p}<0.05)$ in P. cultifera from the Tunisian harbours. All tested parameters (CAT, GST, TBARS, GSH, MTs and SOD) were positively correlated with the abiotic parameters and the trace metal concentrations $(r \geq 0.320 ; p<0.05)$. 
Table 3. - Seasonal variation in the oxidative stress biomarkers in P. cultrifera tissues collected from the port of Rades (S1) and the Punic port of Carthage (S2).

\begin{tabular}{lccccc}
\hline Parameters & Sites & Spring & Summer & Autumn & Winter \\
\hline \multirow{2}{*}{ TBARS } & S1 & $2.39 \pm 0.12$ & $5.01 \pm 0.14^{\ldots \#}$ & $1.71 \pm 0.26$ & $1.79 \pm 0.41$ \\
& S2 & $1.58 \pm 0.31^{*}$ & $3.63 \pm 0.32^{*}$ & $1.02 \pm 0.13$ & $1.33 \pm 0.46$ \\
AChE & S1 & $29.39 \pm 2.90$ & $17.55 \pm 1.91$ & $18.58 \pm 1.99$ & $52.78 \pm 2.53^{\# \# \#}$ \\
& S2 & $36.19 \pm 1.16$ & $23.56 \pm 3.1^{*}$ & $19.32 \pm 1.97$ & $57.50 \pm 2.77$ \\
MTs & S1 & $0.07 \pm 0.00$ & $0.14 \pm 0.01^{\# \#}$ & $0.07 \pm 0.00$ & $0.04 \pm 0.00$ \\
GSH & S2 & $0.05 \pm 0.00^{* * *}$ & $0.11 \pm 0.00^{* * *}$ & $0.06 \pm 0.00^{*}$ & $0.04 \pm 0.00$ \\
& S1 & $0.40 \pm 0.05$ & $0.55 \pm 0.09^{\# \# \#}$ & $0.32 \pm 0.08$ & $0.17 \pm 0.042$ \\
SOD & S2 & $0.24 \pm 0.02^{* * *}$ & $0.44 \pm 0.06^{*}$ & $0.28 \pm 0.03$ & $0.15 \pm 0.015$ \\
& S1 & $5.12 \pm 0.87$ & $6.93 \pm 0.56$ & $3.27 \pm 0.46$ & $1.90 \pm 0.352^{\# \# \#}$ \\
CAT & S2 & $2.61 \pm 0.57^{* * *}$ & $6.14 \pm 0.64^{*}$ & $2.76 \pm 0.35^{*}$ & $1.67 \pm 0.184$ \\
& S1 & $53.73 \pm 2.66$ & $101.90 \pm 3.78^{\# \# \#}$ & $46.80 \pm 9.49$ & $41.49 \pm 1.05$ \\
GST & S2 & $49.10 \pm 9.02^{*}$ & $83.17 \pm 6.78^{* *}$ & $33.71 \pm 8.60^{*}$ & $30.16 \pm 2.43^{*}$ \\
& S1 & $57.58 \pm 2.82$ & $190.30 \pm 6.09^{\# \#}$ & $33.49 \pm 1.45$ & $41.41 \pm 1.69$
\end{tabular}

The results are represented as mean $\pm \mathrm{sd}(\mathrm{n}=20$ individuals).

The statistical differences between sampling sites are represented at $5 \%$ : ${ }^{*}<0.05 ; * * \mathrm{p}<0.01 ; * * * \mathrm{p}<0.001$ using one-way ANOVA.

The statistical differences between seasons are represented at 5\%: $\# \mathrm{p}<0.05 ; \# \# \mathrm{p}<0.01 ; \# \# \mathrm{p}<0.001$ using one-way ANOVA.

TBARS, thiobarbituric acid; AChE, acetylcholinesterase; MTs, metallothionein; GSH, glutathione; SOD, superoxide dismutase; CAT, catalase; GST, glutathione-S-transferase.
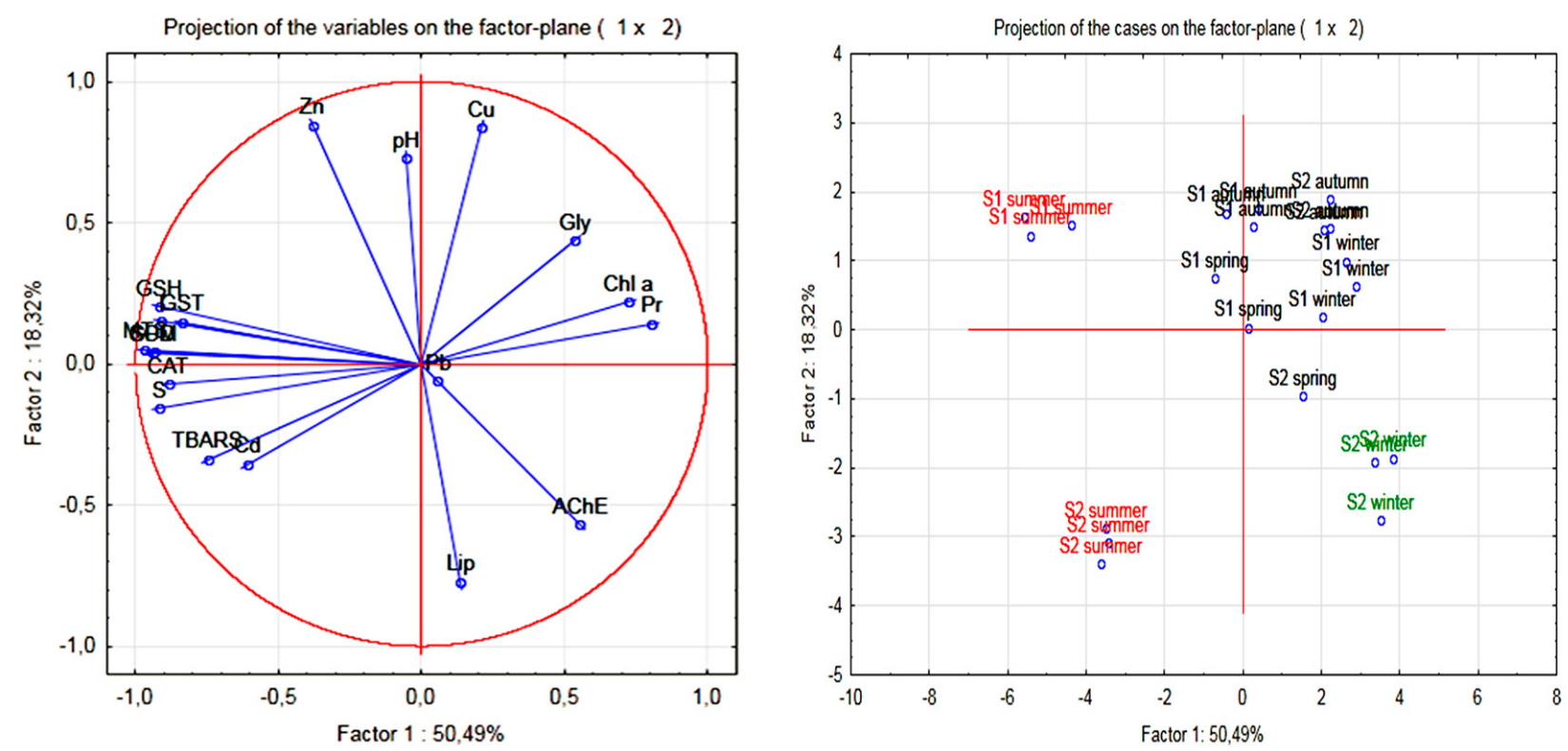

Fig. 4. - Results of PCA represented by two factors $(\mathrm{F} 1=50.49 \%$ and $\mathrm{F} 2=18.32 \%)$ and produced by biochemical variables and trace element concentrations in P. cultrifera from two sites in the Gulf of Tunis. Pr, proteins; Lip, lipids; Gly, glycogen; TBARS, thiobarbituric acid; CAT, catalase; SOD, superoxide dismutase; GSH, glutathione; GST, glutathione-S-transferase; AChE, acetylcholinesterase; MT, metallothionein; $\mathrm{Cd}$, cadmium; $\mathrm{Zn}$, zinc; $\mathrm{Cu}$, cooper; $\mathrm{Pb}$, lead; T, temperature; $\mathrm{S}$, salinity; $\mathrm{Chl} a$, chlorophyll $a$. (A) Projection of the variables on the factorplane 1-2. (B) Projection of the cases on the factor-plane 1-2. 
Table 4. - The matrix of correlation between the analysed parameters and the sampled P. cultrifera.

\begin{tabular}{cccccccc}
\hline & $\mathrm{T}{ }^{\circ} \mathrm{C}$ & $\mathrm{S} \mathrm{psu}$ & $\mathrm{SPM}$ & $\mathrm{Cd}$ & $\mathrm{Zn}$ & $\mathrm{Cu}$ & $\mathrm{Pb}$ \\
\hline CAT & $0.327^{*}$ & $0.327^{*}$ & - & - & - & - & - \\
$\mathrm{AChE}$ & $-0.529^{* *}$ & $0.544^{* *}$ & $0.364^{*}$ & - & $-0.540^{* *}$ & $-0.590^{*}$ & - \\
GST & $0.520^{* *}$ & - & - & - & $0.458^{* *}$ & - & - \\
TBARS & $0.641^{* *}$ & $0.320^{*}$ & - & $0.451^{*}$ & - & - & - \\
CSH & $0.588^{* *}$ & $0.509^{* *}$ & $0.405^{*}$ & $0.536^{* *}$ & $0.557^{* *}$ & - & - \\
MTs & $0.607^{* *}$ & $0.666^{* *}$ & $0.555^{* *}$ & $0.510^{* *}$ & $0.418^{*}$ & - & - \\
SOD & $0.689^{* *}$ & $0.478^{* *}$ & $0.601^{* *}$ & $0.532^{* *}$ & $0.558^{* *}$ & - & - \\
Proteins & - & - & $-0.678^{* * *}$ & $-0.547 * *$ & - & - & - \\
Lipids & $-0.736^{* * *}$ & $-0.523^{* *}$ & $-0.772^{* * *}$ & - & $-0.644^{* * *}$ & $-0.443^{*}$ & - \\
Glycogen & $-0.451^{*}$ & - & $-0.582^{* *}$ & - & - & - \\
\hline
\end{tabular}

TBARS, thiobarbituric acid; AChE, acetylcholinesterase; MTs, metallothionein; GSH, glutathione; SOD, superoxide dismutase; CAT, catalase; GST, glutathione-S-transferase; $\mathrm{T}^{\circ} \mathrm{C}$, temperature; $\mathrm{S}$ psu, salinity; SPM, suspended matter; $\mathrm{Cd}$, cadmium; $\mathrm{Zn}$, zinc; $\mathrm{Cu}$, cooper; $\mathrm{Pb}$, lead. The significant correlation is presented by $* \mathrm{p}<0.05 ; * * \mathrm{p}<0.01$ and $* * * \mathrm{p}<0.001$.

\section{DISCUSSION}

Over the past decades, aquatic ecosystems have suffered from an increase in anthropogenic pollution due to the presence of toxic contaminants (hydrocarbons, pesticides and heavy metals) and other environmental factors (hypoxia, changes in temperature and salinity) (Campillo et al. 2013). Several studies have revealed the effectiveness of marine invertebrates such as $P$. cultrifera as a bioindicator and sentinel organisms for toxicological studies in coastal waters (Guemouda et al. 2014, Snani et al. 2015, Meghlaoui et al. 2015). They are known to accumulate metals in their tissues and survive in contaminated environments, and they are herbivores, have sensitivity and resistance to contaminants and are relatively easy to collect, handle, culture and transport (King et al. 2004).

Spatial and temporal variations in metal concentrations were observed between the two sampling sites of the port of Rades (S1) and the Punic port of Carthage (S2), most likely resulting from the high temperature and evaporation, because in summer metal accumulation shows a significant positive correlation with water parameters such as temperature $(p<0.05)$. The difference in accumulation of metals in the two populations probably indicated the anthropogenic discharges of industrial activities and maritime traffic in the port of Rades. In agreement with this hypothesis, several studies have shown a high accumulation of metals in polychaetes during the warm season. Rouhi et al. (2007) demonstrated that in spring and summer metals were accumulated mostly in the whole soft tissues of two polychaete species (Sabellaria alveolata and Arenicola grubii) collected from the coastline of Jorf Lasfar, Morocco. These findings are probably related to environmental factors and the physiological activity of the animals. Furthermore, Bat et al. (2019) showed a significant difference of metal accumulation between seasons in polychaetes on the shores of Sinop in the Black Sea.

As a metal binding protein, metallothionein (MT), a non-enzymatic antioxidant rich in cysteine and with a low molecular weight, plays a key role in cell defence in addition to ROS generation (Viarengo et al. 1999). Our data showed a higher MT level in S1 than in S2, probably reflecting an adaptative response of the sampled species to the toxic effects induced by trace metal accumulation. This result was confirmed by a positive correlation between MT level and the tested metals in

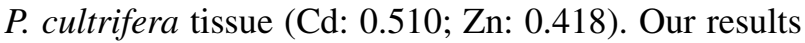
were correlated with those of Suriya et al. (2012) and Won et al. (2008), who demonstrated that trace metal accumulation can generate ROS in Capitella capitela and Perinereis nunta, which in turn contributes to an enhancement of MT level.

Environmental agents such as metals generate intracellular imbalance and stimulate ROS, causing oxidative stress. The biological targets for these highly reactive oxygen species are lipids and proteins, which cause oxidations through the generation of hydroxyl and free radicals from $\mathrm{H}_{2} \mathrm{O}_{2}$ via the Fenton reaction, and can adversely affect cells by producing lipid peroxidation of intracellular membranes (Bejaoui et al. 2019). There is considerable evidence that lipid peroxidation, as measured by TBARS levels, could be proposed as a biomarker of membrane lipid damage because it is considered a by-product of lipid oxidative damage (Freitas et al. 2012). Our data show lower lipid content in S1 than in S2, which correlates with the increase in the TBARS level mainly in summer. This increase in the TBARS level and decreases in lipid content appears to be due to metal uptake, which accelerates the ability to scavenge ROS by extreme production of lipid peroxides resulting from alteration of membrane fluidity and integrity (Chetoui et al. 2019). Previous studies conducted on polychaetes such as Hediste diversicolor 
from contaminated sites on the southwestern Iberian coast (Gomes et al. 2013) and the Oued Souss estuary in the Bay of Agadir, Morocco (Ait Alla et al. 2006) revealed similar increases in TBARS levels. This may be linked to several factors, including metal concentration $(\mathrm{Cd}, \mathrm{Pb}$, etc.) and environmental changes (temperature, salinity, etc.), as described by Sun and Zhou (2008) and Freitas et al. (2015) on Hediste diversicolor and Diopatra neapolitana, respectively. Also, Zhao et al. (2013) found that a high salinity level may increase the potential ecological risk of metal accumulation by generating chemical mobility, thus crossing the biological barriers and interacting with the components of the cellular membranes, causing alterations in their permeability and lipid peroxidation. Our results also showed a significant positive correlation between TBARS levels and $\mathrm{Cd}(0.735)$, salinity (0.420) and temperature (0.641) for polychaetes collected from S2.

Several studies have demonstrated that trace metal accumulation in marine organisms alters their biochemical composition, including proteins and glycogen (Bejaoui et al. 2019). Among these macromolecules, proteins are abundant in biological tissues, having high rate constants for reaction with many species, which is why these proteins are the main target for biological oxidants (Wang et al. 2019). Therefore, oxidant formation is the main consequence of protein damage both externally and within cells. The occurrence of protein reduction in the $P$. cultrifera tissues from $\mathrm{S} 1$ was probably due to excess free radical generation under metal accumulation. Both high lipid peroxidation and protein oxidation may be due to metal contamination, as reported in Mytillus galloprovincialis by Bouki et al. (2013), who suggested that metal contamination affects the amount of protein and increases TBARS levels. Our data show a similar glycogen content between the two sampled harbours in summer and winter, whereas in spring and autumn content was higher in S2. Our results were in accordance with those of previous studies carried out on aquatic organisms, which showed that proximate composition decreased when species were exposed to anthropogenic pollution (Douhri and Sayah 2009, Bejaoui et al. 2019).

The effect of environmental metal pollution on $P$. cultrifera tissue mechanism was also assessed through AChE activity. AChE is present in the neuromuscular junctions and cholinergic synapses of the central nervous system and terminates the signal transmission by hydrolysing acetylcholine (ACh), a neurotransmitter that conducts nerve impulses across neuromuscular junctions (Lodish et al. 2000). Its inhibition can be seen as an early warning biomarker of contaminant risks (Cravo et al. 2012). Our results showed inhibition of AChE activity in specimens taken from the port of Rades. Snani et al. (2015) suggest that the decrease in $\mathrm{AChE}$ release could be induced by the accumulation of trace metals in Perinereis cultrifera from the eastern coast of Algeria. Similar observations have been reported in Hediste diversicolor and Patella vulgate collected from polluted sites of Bay of Tangier in Morocco (Douhri and Sayah 2009). In addition, our results showed increases in AChE activity in winter and de- creases in summer. Moulton et al. (1996) showed that high environmental temperature caused the inhibition of AChE activity in Elliptio complenata mussels. Additionally, Scaps and Borot (2000) demonstrated that salinity and temperature can also affect acetylcholinesterase activity in Hediste diversicolor.

At the cellular level, the functional changes in redox statistics induced by ROS production leads to alterations in cellular metabolism. This damaging action greatly increases the responses of enzymes antioxidants such as SOD, GST CAT and GSH levels (Cravo et al. 2012). SOD, CAT and GST are three major antioxidant enzymes in the cells. \#SOD is the primary defence line against oxygen-derived free radicals and catalyses the dismutation of the superoxide anion $\left(\mathrm{O}_{2}^{--}\right)$into hydrogen peroxide $\left(\mathrm{H}_{2} \mathrm{O}_{2}\right)$, which changes into $\mathrm{H}_{2} \mathrm{O}$ and $\mathrm{O}_{2}$ through CAT\# (Ma et al. 2017). CAT is one of the enzymes involved in reduction of $\mathrm{H}_{2} \mathrm{O}_{2}$ via the Fenton reaction (Chance et al. 1979). GST protects cells against trace element-induced toxicity by deactivating the cytotoxic and genotoxic compounds, catalysing the S-conjugation and reducing GSH (Salinas and Wong 1999).

We found higher SOD and CAT activity in S1 than in $\mathrm{S} 2$, most probably reflecting an adaptive response of those species to remove the harmful effects of ROS generation against environmental stressors, as reported by Carregosa et al. (2014). In addition, increased activities have been reported in several fish and invertebrate species collected from polluted sites (Jebali et al. 2007, Bejaoui et al. 2020). As shown in the study of Ait Alla et al. (2006), these enzymatic activities increased in $\mathrm{He}$ diste diversicolor collected from the Oued Souss (Bay of Agadir, Morocco) before implantation of wastewater treatment. Douhri and Sayah (2009) also reported an increase in CAT activity in two marine invertebrates, Hediste diversicolor and Patella vulgate, taken from polluted sites of the Bay of Tangier in Morocco. Our findings are also similar to those obtained for $P$. cultrifera collected from three sites impacted with different levels of anthropogenic pollution on the eastern coasts of Algeria (Guemouda et al. 2014). The increase in enzymatic activities could also be explained by the higher concentration of bio-accumulated metals, which causes oxidative stress and an antioxidant response (Gaete et al. 2017). However, a significant correlation was observed between $\mathrm{Cd}, \mathrm{Zn}$ and SOD activity as well as $\mathrm{Zn}$ and GST activity (Table 4), suggesting that these metals are bioavailable and responsible for the variation in enhancement of the activities of these antioxidants.

The results of seasonal variations in GST activity at each site showed that it was highest in summer and higher in the port of Rades (S1) than the Punic port of Carthage (S2) throughout the study period $(\mathrm{p}<0.05)$. In addition, this enzyme plays a role in cellular protection against oxidative stress, which can be triggered by pollutants such as metals, PCBs and PAHs (Michel et al. 1998). These findings are similar to those obtained for the worms Hediste diversicolor collected from the polluted estuary of the Seine (Durouet al. 2007). To substantiate the mechanisms underlying trace metal accumulation, GSH was also examined. This non-en- 
zymatic antioxidant is the most important cytosolic sulfhydryl compound that acts as a reducing and protective agent against intensive toxic substances, including trace metals through their $-\mathrm{SH}$ groups (Das et al. 2017). Our results showed a higher GSH level in S1 than in S2, which could be a result of increased synthesis and neutralization of ROS via the thiol group. Dissimilar studies on polychaetes have shown a decrease in GSH level in relation to trace metal accumulation (Lv et al. 2016). According to the above results, the significant relationship between antioxidant biomarkers (mainly GSH, SOD and GST) and the concentrations of metals (mainly $\mathrm{Cd}$ and $\mathrm{Zn}$ ) in $P$. cultrifera tissue suggest the activation of the mechanisms of detoxification due to the generation of ROS. These findings are similar to those obtained by Cataldo et al. (2011) in earthworms at sites contaminated by metals and by Gaete et al. (2017) in Perinereis gualpensis from estuaries of central Chile.

\section{CONCLUSION}

In conclusion, in different seasons and geographical locations $P$. cultrifera shows different physiological responses. In this study, we have assessed the effects of anthropogenic pollution in terms of metal accumulation, antioxidant response and alteration in proximate composition in relation to seasonal change in $P$. cultrifera tissues. The results clearly show that $\mathrm{S} 1$ is more affected by anthropic pollution than $\mathrm{S} 2$. Our study has identified some insights into anthropogenic pollution at the harbour sites, but further studies on metal accumulation in sediments and exposure of $P$. cultrifera to metals are still required to provide general information about the health status of these coastal harbours.

\section{ACKNOWLEDGEMENTS}

This study received no specific grant from any funding agency in the public, commercial or not-for-profit sectors. We thank the editor and anonymous reviewers for their constructive comments and suggestions, which greatly contributed to improving the quality of the paper.

We also thank all the members of the laboratory of Ecology, Biology and Physiology of aquatic organisms, Faculty of Sciences of Tunis, University of Tunis El Manar, in particular Dr. Safa Bejaoui for his help and support.

\section{CONFLICT OF INTEREST}

The authors declare that they have no competing interests.

\section{REFERENCES}

Aebi H. 1984. Catalase in Vitro. Method. Enzymol. 105: 121-126. https://doi.org/10.1016/S0076-6879(84)05016-3

Aissaoui A., Dhib A., Reguera B., et al. 2014. First evidence of cell deformation occurrence during a Dinophysis bloom along the shores of the Gulf of Tunis (SW Mediterranean Sea). Harmful Algae 39: 191-201. https://doi.org/10.1016/j.hal.2014.07.017
Ait Alla A., Mouneyrac C., Durou C., et al. 2006. Tolerance and biomarkers as useful tools for assessing environmental quality in the Oued Souss estuary (Bay of Agadir, Morocco). Comp. Biochem. Phys. C. 143: 23-29. https://doi.org/10.1016/j.cbpc.2005.11.015

Aminot A., Chaussepied C. 1983. Manuel des analyses chimiques en milieu marin. Centre National d'Exploitation des Océans, Brest, 395 pp.

Antit M. 2012. Caractérisation des communautés des Mollusques dans des milieux littoraux de la baie de Tunis, Thèse de Doctorat, Faculté des Sciences de Tunis, 396 pp.

Bat L., Şahin F., Öztekin A. 2019. Assessment of heavy metals pollution in water and sediments and Polychaetes in Sinop shores of the Black Sea. KSU Tarım ve Doğa Derg. 22: 806-816. https://doi.org/10.18016/ksutarimdoga.v22i45606.535882

Beauchamp C., Fridovich I. 1971. Superoxide dismutase: improved assays and an assay applicable to acrylamide gels. Anal. Biochem. 44: 276-277. https://doi.org/10.1016/0003-2697(71)90370-8

Bejaoui S., Boussoufa D., Tir M., et al. 2017. DNA damage and oxidative stress in digestive gland of Venerupis decussata collected from two contrasting habitats in the southern Tunisian coast: biochemical and histopathological studies. Cah. Biol. Mar. 58: 123-135.

Bejaoui S., Fouzai C., Trabelsi W., et al. 2019. Evaluation of lead chloride toxicity on lipid profile in Venus verrucosa gills. Int. J. E. Res. 13: 793-800. https://doi.org/10.1007/s41742-019-00218-4

Bejaoui S., Michan C., Telahigue K., et al. 2020. Metal body burden and tissue oxidative status in the bivalve Venerupis decussata from Tunisian coastal lagoons. Mar. Environ. Res. 159: 105000. https://doi.org/10.1016/j.marenvres.2020.105000

Bodin N., N'Gom Kâ R., Le Loc'h F., et al. 2011. Are exploited mangrove molluscs exposed to Persistent Organic Pollutant contamination in Senegal, West Africa? Chemosphere. 84: 318-327. https://doi.org/10.1016/j.chemosphere.2011.04.012

Bouki E., Dimitriadis V.K. Kaloyianni M., et al. 2013. Antioxidant and pro-oxidant challenge of tannic acid in mussel hemocytes exposed to cadmium. Mar. Environ. Res. 85: 591-604. https://doi.org/10.1016/j.marenvres.2012.12.005

Bradford M. 1976. Rapid and sensitive method for the quantitation of microgram quantities of protein utilizing the principle of protein-dye binding. Anal. Biochem. 72: 248-254. https://doi.org/10.1016/0003-2697(76)90527-3

Campillo J.A., Albentosa M.N., Valdes J., et al. 2013. Impact assessment of agricultural inputs into a Mediterranean coastal lagoon (Mar Menor, SE Spain) on transplanted clams $(R u$ ditapes decussatus) by biochemical and physiological responses. Aquat. Toxicol. 142-143: 365-379. https://doi.org/10.1016/j.aquatox.2013.09.012

Carr R.S., Neff J.M. 1984. Quantitative semi-automated enzymatic assay for tissue glycogen. Comp. Biochem. Phys. B. 77: 447-449. https://doi.org/10.1016/0305-0491(84)90258-X

Carregosa V., Velez C., Soares A.M.V.M., et al. 2014. Physiological and biochemical responses of three Veneridae clams exposed to salinity changes. Comp. Biochem. Phys. B. 177-178: 1-9. https://doi.org/10.1016/j.cbpb.2014.08.001

Cataldo J., Hidalgo M.E., Neaman A., et al. 2011. Use of molecular biomarkers in Eisenia foetida to assess copper toxicity in agricultural soils affected by mining activities. J. Soil. Sci. Plant. Nut.11: 57-70.

Chance B., Sies H., Boveris A. 1979. Hydroperoxide metabolism in mammalian organs. Physiol. Rev. 59: 527-605. https://doi.org/10.1152/physrev.1979.59.3.527

Chetoui I., Bejaoui S., Trabelsi W., et al. 2019. Exposure of Mactra corallina to acute doses of lead: effects on redox status, fatty acid composition and histomorphological aspect. Drug Chem. Toxicol. https://doi.org/10.1080/01480545.2019.1693590

Chouikh N., Gillet P., Langston W.J., et al. 2019. First investigation of the composition and spatial distribution of polychaete feeding guilds from Essaouira protected coastal area. Appl. Ecol. Env. Res. 17: 3231-3249. https://doi.org/10.15666/aeer/1702_32313249

Cravo A., Pereira C., Gomes T., et al. 2012. A multibiomarker approach in the clam Ruditapes decussatus to assess the impact of pollution in the Ria Formosa lagoon, South Coast of Portugal. Mar. Environ. Res. 75: 23-34. https://doi.org/10.1016/j.marenvres.2011.09.012 
Das D., Moniruzzaman M., Sarbajna A., et al. 2017. Effect of heavy metals on tissue-specific antioxidant response in Indian major carps. Environ. Sci. Pollu. Res. 24: 18010-18024. https://doi.org/10.1007/s11356-017-9415-5

Di Salvatore P., Calcagno J.A., Ortíz N., et al. 2013. Effect of seasonality on oxidative stress responses and metal accumulation in soft tissues of Aulacomya atra, a mussel from the South Atlantic Patagonian coast. Mar. Environ. Res. 92: 244-252. https://doi.org/10.1016/j.marenvres.2013.10.004

Douhri H., Sayah F. 2009. The use of enzymatic biomarkers in two marine invertebrates Nereis diversicolor and Patella vulgata for the biomonitoring of Tangier's bay (Morocco). Ecotox. Environ. Safe. 72: 394-399. https://doi.org/10.1016/j.ecoenv.2008.07.016

Durchon M. 1957. Problèmes posés par le comportement des néréidiens au moment de leur reproduction. Ann. Biol. 33: $31-42$.

Durou C., Smith B.D., Romeo M., et al. 2007. From biomarkers to population responses in Nereis diversicolor: Assessment of stress in estuarine ecosystems. Ecotox. Environ. Safe. 66: 402-411.

https://doi.org/10.1016/j.ecoenv.2006.02.016

Ellman G.L. 1959. Tissue sulhydryl groups. Arch. Biochem. Biophys. 82: 70-77. https://doi.org/10.1016/0003-9861(59)90090-6

Ellman G.L., Courtney K.D., Andres V., et al. 1961. A new and rapid colorimetric determination of acetylcholinesterase activity. Biochem. Pharmacol.7: 88-95. https://doi.org/10.1016/0006-2952(61)90145-9

Freitas R., Ramos Pinto L., Sampaio M., et al. 2012. Effects of depuration on the element concentration in bivalves: Comparison between sympatric Ruditapes decussates and Ruditapes philippinarum. Estuar. Coast. Shelf Sci. 110: 43-53. https://doi.org/10.1016/j.ecss.2012.01.011

Freitas R., Pires A., Velez C., et al. 2015. The effects of salinity changes on the Polychaete Diopatra neapolitana: impacts on regenerative capacity and biochemical markers. Aquat. Toxicol.163: 167-176. https://doi.org/10.1016/j.aquatox.2015.04.006

Frings C.S., Fendley T.W., Dunn R.T., et al. 1972. Improved determination of total serum lipids by the sulfo-phospho-vanillin reaction. Clin. Chem. 18: 673-674. https://doi.org/10.1093/clinchem/18.7.673

Gaete H., Álvarez M., Lobos G., et al. 2017. Assessment of oxidative stress and bioaccumulation of the metals $\mathrm{Cu}, \mathrm{Fe}, \mathrm{Zn}, \mathrm{Pb}, \mathrm{Cd}$ in the polychaete Perinereis gualpensis from estuaries of central Chile. Ecotox. Environ. Safe.145: 653-658. https://doi.org/10.1016/j.ecoenv.2017.07.073

Ghirardini V.A., Cavallini L., Delaney E., et al. 1999. H. diversicolor, N. succinea and P. cultrifera (Polychaeta: Nereididae) as bioaccumulators of cadmium and zinc from sediments: Preliminary results in the Venetian lagoon (Italy). Toxicol. Environ. Chem. 71: 457-474. https://doi.org/10.1080/02772249909358815

Gomes T., Gonzalez-Rey M., Rodriguez-Romero A., et al. 2013. Biomarkers in Nereis diversicolor (Polychaeta: Nereididae) as management tools for environmental assessment on the southwest Iberian coast. Sci. Mar. 77S1: 69-78. https://doi.org/10.3989/scimar.03731.27F

Grube E. 1840. Actinien, Echinodermen und Würmer des Adriatischen und Mittlemeers. Könisberg, 1840, 92 pp.

Guemouda M., Meghlaoui Z., Daas T., et al. 2014. Monitoring pollution in East Algerian coasts using biochemical markers in the polychaete annelid Perinereis cultrifera. Ann. Biol. Res. 5: 31-40.

Habig W.H., Pabst M.J., Jakoby W.B. 1974. Glutathione S-transferases, the first enzymatic stepin mercapturic acid formation. J. Biol. Chem. 249: 7130-7139. https://doi.org/10.1016/S0021-9258(19)42083-8

Halliwell B. 2007. Biochemistry of oxidative stress. Biochem. Soc. T. 35: 1147-1150. https://doi.org/10.1042/BST0351147

Han Q., Jiang X., Wang X. 2016. The polychaete feeding guild composition in the Sishili Bay, the northern Yellow Sea, China. J. Mar. Biol. Assoc. UK. 96: 1083-1092. https://doi.org/10.1017/S0025315415001873

Jebali J., Banni M., Alves de Almeida E., et al. 2007. Oxidative DNA damage levels clam Ruditapes decussatus as pollu- tion biomarkers of Tunisian marine environment. Environ. Monit. Assess. 124: 195-200. https://doi.org/10.1007/s10661-006-9217-6

Jollow D.J., Mitchell J.R., Zampaglione N., et al. 1974. Bromobenzene-induced liver necrosis. Protective role of glutathione and evidence for 3,4-bromobenzene oxide as the hepatotoxic metabolite. Pharmacology 11: 151-169. https://doi.org/10.1159/000136485

King C.K., Dowse M.C., Simpson S.L., et al. 2004. An assessment of five Australian polychaetes and bivalves for use in whole-sediment toxicity tests: toxicity and accumulation of copper and zinc from water and sediment. Arch. Environ. Con. Toxicol. 47: 314-323. https://doi.org/10.1007/s00244-004-3122-1

Knight J.A., Pieper R.K., McClellan L. 1988. Specificity of the thiobarbituric acid reaction: its use in studies of lipid peroxidation. Clin. Chem. 34: 2433-2438. https://doi.org/10.1093/clinchem/34.12.2433

Li L., Liu X., You L., et al. 2012. Uptake pathways and subcellular fractionation of $\mathrm{Cd}$ in the polychaete Nereis diversicolor. Ecotoxicology 21:104. https://doi.org/10.1007/s10646-011-0770-6

Lodish H., Berk A., Zipursky S.L., et al. 2000. Molecular Cell Biology. 4th edition. New York: W. H. freeman.

Lv L., Dong X., Lv F., et al. 2016.Antioxidant enzymes responses of polychaete Perinereis aibuhitensis following chronic exposure to $17 \beta$-estradiol. Ital. J. Anim. Sci. 15: 552-557. https://doi.org/10.1080/1828051X.2016.1194172

Ma X., Deng D., Chen W. 2017. Inhibitors and Activators of SOD, GSH-Px, and CAT. In: Sentürk M. (ed.), Enzyme Inhibitors and Activators, Intech. Open. https://doi.org/10.5772/65936

Meghlaoui Z., Guemouda M., Snani M., et al. 2015. Effect of oil pollution on polychaete annelids in the Algerian East coast. J. Entomol. Zool. Stud. 3: 339-343.

Michel X., Narbonne J.F., Mora P., et al. 1998. Utilisation de biomarqueurs pour la surveillance de la qualité de l'environnement. In: Lagadic L., Caquet T., Amiard J.C., et al. (eds), Lavoisier Tec \& Doc, Paris, New York, Londres, pp. 9-30.

Moulton W.N., Howard T., Pruett M. 1996. Business Failure Pathways: Environmental Stress and Organizational Response. J. Manage. 22: 571-595. https://doi.org/10.1016/S0149-2063(96)90025-2

Mouneyrac C., Geffard A., Amiard J.C., et al. 2000. Metallothioneinlike proteins in Macoma balthica: effects of metal exposure and natural factors. Can. J. Fish. Aquat. Sci. 57: 34-42. https://doi.org/10.1139/f99-183

Paraskevopoulou V., Zeri C., Kaberi H., et al. 2014. Trace metal variability, background levels and pollution status assessment in line with the water framework and marine strategy framework EU Directives in the waters of a heavily impacted Mediterranean Gulf. Mar. Pollut. Bull. 87: 323-337. https://doi.org/10.1016/j.marpolbul.2014.07.054

Petrovic S., Ozretic B., Krajnovic-Ozretic M., et al. 2001. Lysosomal membrane stability and metallothioneins in digestive gland of mussels (Mytilus galloprovincialis Lam.) as biomarkers in afield study. Mar. Pollut. Bull. 42: 1373-1378. https://doi.org/10.1016/S0025-326X(01)00167-9

Rouabah A., Scaps P. 2003. Life cycle and population dynamics of the polychaete Perinereis cultrifera from the Algerian Mediterranean Coast. P.S.Z.N.: Mar. Ecol. 24: 85-99. https://doi.org/10.1046/j.1439-0485.2003.03796.x

Rouhi A., Sif J., Ferssiwi A., et al. 2007. Bioaccumulation de quelques éléments métalliques par deux espèces d'Annélides Polychètes du littoral de Jorf Lasfar (région d'El Jadida, Maroc). Bull. Inst. Sci. Rabat. 29: 81-87.

Salinas A.E. Wong M.G. 1999.Glutathione S-transferases-a review. Curr. Med. Chem. 6: 279309.

Scaps P., Borot O. 2000. Acetylcholinesterase activity of the polychaete Nereis diversicolor: effects of temperature and salinity. Comp. Biochem. Physiol. C. 125: 377-383. https://doi.org/10.1016/S0742-8413(00)00087-6

Scaps P., Retière C., Desrosiers G., et al. 1992. Dynamique d'une population de Perinereis cultrifera (Grube) de la côte nord Bretagne. Cah. Biol. Mar. 33: 477-194.

Snani M., Meghlaoui Z., Maamcha O., et al. 2015. Laying period and biomarkers of the polychaete Perinereis cultrifera from the eastern coast of Algeria subjected to marine pollution. J. Entomol. Zool. Stud. 3: 249-254. 
Souissi S., Daly Yahia-Kéfi O., Daly Yahia M.N. 2000. Spatial characterization of nutrient dynamics in the Bay of Tunis (south western Mediterranean) using multivariate analyses: consequences for phyto- and zooplankton distribution. J. Plankton Res. 22: 2039-2059. https://doi.org/10.1093/plankt/22.11.2039

Sun F., Zhou Q. 2008. Oxidative stress biomarkers of the polychaete Nereis diversicolor exposed to cadmium and petroleum hydrocarbons. Ecotox. Environ. Safe.70: 106114. https://doi.org/10.1016/j.ecoenv.2007.04.014

Sureda A., Box A., Tejada S., et al. 2011. Biochemical responses of Mytilus galloprovincialis as biomarkers of acute environmental pollution caused by the Don Pedro oil spill (Eivissa Island, Spain). Aquat. Toxicol. 101: 540-549. https://doi.org/10.1016/j.aquatox.2010.12.011

Suriya J., Bharathiraja S., Sekar V., et al. 2012. Metallothionein induction and antioxidative responses in the estuarine polychaeta Capitella capitata (Capitellidae). Asian Pac. J. Trop. Biomed. 2: 1052-1059. https://doi.org/10.1016/S2221-1691(12)60360-8

Tlili S., Minguez L., Giamberini L., et al. 2013. Assessment of the health status of Donax trunculus from the Gulf of Tunis using integrative biomarker indices. Ecol. Indic. 32: $285-293$

https://doi.org/10.1016/j.ecolind.2013.04.003

Usero J., Morillo J., Gracia I. 2005. Heavy metal concentrations in molluscs from the Atlantic coast of southern Spain. Chemosphere. 59: 1175-1181. https://doi.org/10.1016/j.chemosphere.2004.11.089

Viarengo A., Ponzano E., Dondero F., et al. 1997. A simple spectrophotometric method for metallothionein evalua- tion in marine organisms: an application to Mediterranean and Antartic molluscs. Mar. Environ. Res. 44: 69-84. https://doi.org/10.1016/S0141-1136(96)00103-1

Viarengo A., Burlando B., Cavaletto M., et al. 1999. Role of metallothionein against oxidative stress in the mussel Mytilus galloprovincialis. Am. J. Physiol. 277: 16121619. https://doi.org/10.1152/ajpregu.1999.277.6.R1612

Wang k., Jiang J., Lei Y., et al. 2019. Targeting Metabolic-Redox Circuits for Cancer Therapy. Trends Biochem. Sci. 44: 5 . https://doi.org/10.1016/j.tibs.2019.01.001

Won E.J., Raisuddin S., Shin K.H. 2008. Evaluation of induction of metallothionein-like proteins (MTLPs) in the polychaetes for biomonitoring of heavy metal pollution in marine sediments. Mar. Pollut. Bull. 57: 544-551. https://doi.org/10.1016/j.marpolbul.2008.02.025

Wu B., Sun R., Yang D. 1985. The Nereidae (Polychaetous annelids) of the Chinese coast. China Ocean Press. Beijing, $234 \mathrm{pp}$.

Yi Yu-jun., Wang Z., Zhang K., et al. 2008. Sediment pollution and its effect on fish through 531 food chain in the Yangtze River. Int. J. Sediment Res. 23: 338-347. https://doi.org/10.1016/S1001-6279(09)60005-6

Zhao S., Feng C., Wang D., et al. 2013. Salinity increases the mobility of $\mathrm{Cd}, \mathrm{Cu}, \mathrm{Mn}$, and $\mathrm{Pb}$ in the sediments of Yangtze Estuary: relative role of sediments' properties and metal speciation. Chemosphere 91: 977-984. https://doi.org/10.1016/j.chemosphere.2013.02.001

Zghal F., Ben Amor Z. 1989. Sur la présence en Méditerranée de la race Perinereis cultrifera (Polychète). Archives de l'institut Pasteur de Tunis 66: 293-301. 